Published in final edited form as:

ACS Infect Dis. 2016 July 8; 2(7): 518-528. doi:10.1021/acsinfecdis.6b00077.

\title{
Glycogen Synthase Kinase $3 \beta$ Promotes the Endocytosis of Transferrin in the African Trypanosome
}

\author{
Paul J. Guyett ${ }^{\dagger}$, Shuangluo Xia ${ }^{\ddagger}$, David C. Swinney ${ }^{\ddagger}$, Michael Pollastri ${ }^{\S}$, and Kojo Mensa- \\ Wilmot ${ }^{*} \dagger$ \\ †Department of Cellular Biology, The Center for Tropical and Emerging Global Diseases, \\ University of Georgia, 724 Biological Sciences Building, Athens, Georgia 30605, United States \\ \#Institute for Rare and Neglected Disease Drug Discovery (IRND3), 897 Independence Avenue \\ \#2C, Mountain View, California 94043, United States \\ $\S$ Department of Chemistry and Chemical Biology, Northeastern University, 417 Egan Building, \\ 360 Huntington Avenue, Boston, Massachusetts 02115, United States
}

\begin{abstract}
Human parasite Trypanosoma brucei proliferates in the blood of its host, where it takes up iron via receptor-mediated endocytosis of transferrin (Tf). Mechanisms of Tf endocytosis in the trypanosome are not fully understood. Small molecule lapatinib inhibits Tf endocytosis in $T$. brucei and associates with protein kinase GSK $3 \beta$ (TbGSK $3 \beta$ ). Therefore, we hypothesized that Tf endocytosis may be regulated by TbGSK3 $\beta$, and we used three approaches (both genetic and small molecule) to test this possibility. First, the RNAi knock-down of TbGSK3 $\beta$ reduced Tf endocytosis selectively, without affecting the uptake of haptaglobin-hemoglobin $(\mathrm{Hp}-\mathrm{Hb})$ or bovine serum albumin (BSA). Second, the overexpression of TbGSK $3 \beta$ increased the Tf uptake. Third, small-molecule inhibitors of TbGSK3 $\beta$, TWS119 $\left(\mathrm{IC}_{50}=600 \mathrm{nM}\right)$, and GW8510 $\left(\mathrm{IC}_{50}=8\right.$ $\mathrm{nM})$ reduced Tf endocytosis. Furthermore, TWS119, but not GW8510, selectively blocked Tf uptake. Thus, TWS119 phenocopies the selective endocytosis effects of a TbGSK3 $\beta$ knockdown. Two new inhibitors of TbGSK3 $\beta$, LY2784544 $\left(\mathrm{IC}_{50}=0.6 \mu \mathrm{M}\right)$ and sorafenib $\left(\mathrm{IC}_{50}=1.7 \mu \mathrm{M}\right)$, were discovered in a focused screen: at low micromolar concentrations, they prevented $\mathrm{Tf}$ endocytosis as well as trypanosome proliferation $\left(\mathrm{GI}_{50}\right.$ 's were 1.0 and $3.1 \mu \mathrm{M}$, respectively).
\end{abstract}

*Corresponding Author mensawil@uga.edu.

Author S.X. is deceased.

Supporting Information

The Supporting Information is available free of charge on the ACS Publications website at DOI: 10.1021/acsinfecdis.6b00077. Additional information on inhibitor screening data, inhibitor chemical structures (SMILES format), CAS numbers, the effect of PKI-166 on endocytosis, the proliferation of TbGSK $3 \beta$ overexpression clones 1 and 2 , and recombinant TbGSK $3 \beta$ purification and activity (PDF)

Author Contributions

Biological experiments were performed by P.J.G. Enzyme assays and compound screens were performed by S.X. Experimental design, data analysis, and manuscript composition were carried out by all authors.

Notes

The authors declare no competing financial interest.

DEDICATION

Dedicated to the memory of Martin John Rogers (1960-2014), who served with passion, extraordinary vision, and dedication as program officer for Tropical Diseases at NIAID (National Institutes of Health). We have lost a warrior and leader. We continue the battle, John. 
These studies show that (a) TbGSK3 $\beta$ regulates Tf endocytosis, (b) TWS119 is a small-molecule tool for investigating the endocytosis of Tf, (c) endocytosis of GPI-anchored TfR and HpHbR are differentially regulated, and (d) the imidazopyridazine aminopyrazole scaffold of LY2784544 is attractive for a hit-to-lead optimization program in antitrypanosome drug discovery.

\section{Graphical abstract}

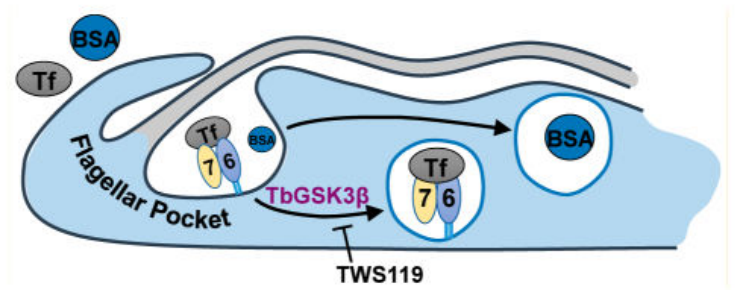

\section{Keywords}

glycogen synthase kinase $3 \beta$; endocytosis; drug discovery; trypanosome; protein kinase

\section{INTRODUCTION}

Trypanosoma brucei is a protozoan parasite that causes human African trypanosomiasis (HAT). During the first stage of infection, the parasite proliferates in the blood and lymph of the vertebrate host, acquiring host transferrin (as an essential source of iron) by receptormediated endocytosis. ${ }^{1}$ T. brucei has a transferrin receptor (TfR) that lacks sequence similarity to human TfR (hTfR). TfR is a GPI-anchored heterodimer of ESAG 6 and ESAG 7 gene products that lack transmembrane and cytoplasmic domains, ${ }^{2-4}$ whereas hTfR is a homodimer comprising transmembrane and cytoplasmic domains. ${ }^{4}$ These differences in receptors for $\mathrm{Tf}$ reflect major differences in endocytosis pathways between the parasite and host, fueling expectations that Tf endocytosis may be a good target for the discovery of pharmacological leads for antitrypanosome drug discovery. ${ }^{5}$

In human cells, $\mathrm{Tf}$ endocytosis is regulated by nonreceptor protein tyrosine kinase Src. ${ }^{6}$ Trypanosomes are predicted to have 190 protein kinases $;{ }^{7}$ however, none are classic protein tyrosine kinases. ${ }^{8}$ Furthermore, no protein kinase has been identified as a regulator of $\mathrm{Tf}$ endocytosis, although a pan-inhibitor of Tyr kinases (tyrphostin-A47) blocks Tf endocytosis in the parasite. ${ }^{9,10}$ Protein kinases that control $\mathrm{Tf}$ endocytosis could be valuable targets for drug discovery because of the importance of Tf uptake for trypanosome viability.

Small-molecule perturbants of cellular processes can be useful tools for studying biological systems. ${ }^{1-13}$ The approach is most valuable for deeply diverged eukaryotes whose signaling pathways have deviated significantly from those found in well-studied systems (e.g., yeast and humans). Lapatinib, a small-molecule inhibitor of human epidermal growth factor receptor (EGFR), ${ }^{14,15}$ blocks Tf endocytosis in T. brucei. (Guyett, P.J., et al., manuscript submitted.) However, $T$. brucei lacks EGFR. Instead, in the trypanosome, lapatinib associates with four proteins including glycogen-synthase kinase $3 \beta$ (TbGSK3 $\beta) .{ }^{16}$ The other three enzymes were either implicated in cell division (Tb427.04.5180 ${ }^{17}$ and 
Tb427.05.800 ${ }^{18}$ ) or had no loss of fitness when knocked down (Tb427.03.1570 $\left.{ }^{19,20}\right)$.

Consequently, we hypothesized that $\mathrm{Tf}$ endocytosis is regulated by TbGSK3 $\beta$.

In this work, we use three methods to establish TbGSK3 $\beta$ as a novel regulator of Tf endocytosis in T. brucei: First, the knockdown of TbGSK $3 \beta$ by RNAi decreased the Tf uptake. Second, the treatment of trypanosomes with small-molecule inhibitors of TbGSK3 $\beta$ reduced $\mathrm{Tf}$ endocytosis. Third, the overexpression of TbGSK3 $\beta$ increases $\mathrm{Tf}$ uptake. Because $\mathrm{Tf}$ endocytosis is essential for trypanosome proliferation ${ }^{21}$ and a knockdown of TbGSK $3 \beta$ compromises trypanosome viability, ${ }^{22}$ we screened a library of compounds to identify new chemotypes that inhibit the enzymatic activity of TbGSK $3 \beta$. These novel TbGSK $3 \beta$ inhibitors were then tested for their effects on Tf endocytosis and trypanosome proliferation. From this directed screen, LY2784544 and sorafenib unexpectedly emerged as inhibitors that are suitable for a follow-up hit-to-lead medicinal chemistry effort in antitrypanosome drug discovery.

\section{RESULTS}

\section{Genetic Knockdown of TbGSK3 $\beta$ Reduces Transferrin Endocytosis}

To test the hypothesis that TbGSK3 $\beta$ regulates Tf endocytosis in T. brucei, we knocked down TbGSK $3 \beta$ using a tetracycline (Tet)-inducible RNA interference (RNAi) system. ${ }^{23}$ After $48 \mathrm{~h}$ of RNAi induction, TbGSK $3 \beta$ protein was undetectable by Western blotting (Figure 1a), a fact that coincided with reduced trypanosome proliferation (Figure 1b).

We tested the effect of TbGSK3 $\beta$ knockdown on trypanosome endocytosis of transferrin after $48 \mathrm{~h}$ of RNAi induction (Figure 1c,d). Induced (+Tet) and uninduced (-Tet) cells were normalized to control trypanosomes that were not transfected with the RNAi vector. In the uninduced cells, Tf endocytosis was measured at $90 \%$ of the amount taken up by control cells. In contrast, TbGSK $3 \beta$ knockdown trypanosomes endocytosed $50 \%$ less transferrin than control cells. Thus, TbGSK $3 \beta$ is required for normal levels of transferrin endocytosis.

To determine if a knockdown of TbGSK $3 \beta$ affected the endocytosis of other macromolecules, the uptake of haptoglobin-hemoglobin (which has a GPI-anchored receptor) ${ }^{24}$ and bovine serum albumin (BSA), a marker for bulk-phase endocytosis, ${ }^{25,26}$ were monitored. Uninduced TbGSK3 $\beta$ RNAi cells endocytosed equivalent amounts of Hp$\mathrm{Hb}$ and BSA as control trypanosomes (Figure 1d). Intriguingly, TbGSK $3 \beta$ knockdown cells endocytosed slightly greater amounts of BSA than did control cells, although the difference in uptake was not statistically significant $(p>0.05)$ (Figure 1d). We conclude that the loss of TbGSK3 $\beta$ does not inhibit Hp-Hb or BSA endocytosis.

\section{Small-Molecule Inhibitors of TbGSK3 $\beta$ Decrease Tf Endocytosis in T. brucei}

To chemically validate TbGSK $3 \beta$ as a regulator of Tf endocytosis in trypanosomes, we tested the effect of two TbGSK $3 \beta$ inhibitors, GW8510 $22,27\left(\mathrm{IC}_{50}=8 \mathrm{nM}\right.$, Table 1) and TWS $119^{28}\left(\mathrm{IC}_{50}=600 \mathrm{nM}\right.$, Table 1, Figure 2a,b) on Tf endocytosis.

GW8510 and TWS119 decreased Tf endocytosis in trypanosomes, with $\mathrm{EC}_{50}$ values of 0.8 and $2.0 \mu \mathrm{M}$, respectively (Figure $2 \mathrm{c}, \mathrm{d}$ ). However, the inhibitors had different effects on bulk- 
phase BSA uptake. GW8510 decreased both Tf and BSA endocytosis (Figure 2c). TWS119 did not decrease BSA or Hp-Hb endocytosis although it inhibited Tf endocytosis (Figure $2 d$ ), phenocopying a genetic knockdown of TbGSK3 $\beta$ (Figure 1d). TWS119 inhibits Tf endocytosis with a selectivity ratio (i.e., $\mathrm{BSA}\left(\mathrm{EC}_{50}\right)$ : $\mathrm{Tf}\left(\mathrm{EC}_{50}\right)$ ) greater than 5 (Table 1). GW8510 is a nonselective inhibitor of endocytosis (selectivity ratio $=1.5$ (Table 1 )); it may have multiple protein targets that include TbGSK3 $\beta$.

The chemical basis for the selective inhibition of Tf endocytosis by TWS119 is not known. To explore the possibility that the property is conferred by its pyrrolopyrimidine chemotype, we tested whether another pyrrolopyrimidine, PKI- $166^{29}$ had similar biological effects. PKI-166 did not inhibit TbGSK3 $\beta$ in vitro $\left(\mathrm{IC}_{50}>20 \mu \mathrm{M}\right)$. Furthermore, PKI-166 did not inhibit the endocytosis of either Tf or BSA (Figure S1). Nevertheless, PKI-166 inhibits trypanosome proliferation (concentration of drug that inhibits growth by $50 \%\left(\mathrm{GI}_{50}\right)=5$ $\mu \mathrm{M}) .{ }^{30}$ We conclude that PKI-166 has a different target other than TbGSK $3 \beta$ and blocks a different physiological pathway than Tf endocytosis. Therefore, the biological effects of TWS119 on TbGSK $3 \beta$ and Tf endocytosis are not intrinsic to the scaffold; the substituents on the pyrrolopyrimidine play a major role in conferring the biochemical and biological effects of TWS119.

\section{Overexpression of TbGSK3 $\beta$ Increases Tf Endocytosis}

We performed a direct test, as opposed to the RNAi study, of the role of TbGSK3 $\beta$ in transferrin endocytosis by over-expressing the enzyme and evaluating the effect on Tf uptake. Production of the enzyme was under the control of a tetracycline inducible T7 RNAP promoter in the pDex777 plasmid. ${ }^{31}$ Two clones selected for analysis both overexpressed TbGSK $3 \beta$ within $3 \mathrm{~h}$ of induction (Figure $3 \mathrm{a}$ ). Continued overexpression (longer than $3 \mathrm{~h}$ ) negatively impacted trypanosome proliferation; slower growth was observed at $6 \mathrm{~h}$ for both clones (Figure S2). Thus, cells induced for $3 \mathrm{~h}$ were used for all subsequent experiments. For clone 1 , the increase in TbGSK $3 \beta$ protein abundance correlated with a significant increase (300\%) in Tf endocytosis $(p<0.05)$ (Figure 3c). Clone 2 overexpressed less TbGSK3 $\beta$ protein (Figure 3c); accordingly, there was less enhancement of Tf uptake (40\% increase) (Figure 3a).

We used TWS119 as a chemical probe of the activity of overexpressed TbGSK3 $\beta$. Our hypothesis was that if the increase in Tf endocytosis (Figure 3c) was due to the overexpressed enzyme, TWS119, an inhibitor of TbGSK3 $\beta$ (Figure 2), would reduce the stimulatory effect of the enzyme on Tf uptake. A schematic of the experimental setup is presented in Figure 3b. For clone 1, TWS119 $(10 \mu \mathrm{M})$ treatment reduced Tf endocytosis driven by TbGSK $3 \beta$ overexpression by $300 \%$ (Figure 3c), bringing it within error of the amount of endocytosis in cells prior to induction of TbGSK $3 \beta$ overexpression (Figure $3 \mathrm{c}$ ). Similar trends were observed with clone 2 , although the magnitude of differences was less, as compared to clone 1 . These data, combined with the RNAi results, indicate that TbGSK $3 \beta$ enzyme levels modulate Tf endocytosis in the trypanosome. 


\section{Two New TbGSK3 $\beta$ Inhibitor Scaffolds}

Since it is involved in a pathway that is essential for trypanosome proliferation in the host, TbGSK $3 \beta$ is a good target for discovery of new antitrypanosomal hits. ${ }^{22,32}$ Toward the goal of finding new hits, we established an in vitro protein kinase assay using purified recombinant full-length TbGSK3 $\beta$ expressed in E. coli with a 6 X His tag. The tagged protein was enriched by immobilized metal afinity chromatography and purified further by size exclusion chromatography (SEC) (Figure S3a). Enzyme activity of recombinant TbGSK3 $\beta$ (rTbGSK3 $\beta$ ) (from SEC fractions 13 through 15) was confirmed using a synthetic peptide substrate (GSM). The $\mathrm{K}_{\mathrm{M}}$ of peptide and ATP substrates were determined (Figure S3b), and found to be within the range previously reported for TbGSK3 $\beta .{ }^{22,33}$

To identify novel inhibitor scaffolds for TbGSK3 $\beta$, we screened a protein tyrosine kinase inhibitor library (Selleck Chemicals) (Table S1) as outlined in Figure 4a. The library of 70 molecules was initially screened with $20 \mu \mathrm{M}$ drug for inhibition of TbGSK $3 \beta$ enzyme activity. Those compounds that inhibited TbGSK $3 \beta>80 \%$ at $20 \mu \mathrm{M}$ were then screened at 2 $\mu \mathrm{M}$. Dose-response curves were generated for any compound with at least $20 \%$ inhibition at $2 \mu \mathrm{M}$. At each step in the screening protocol, the compounds were also tested for inhibition of the coupled enzymes in the ADP Quest (DiscoverRx, Fremont, CA) assay, in order to verify that the observed inhibition was due to interaction with TbGSK $3 \beta$ instead of the coupled enzymes (Table S1). A compound was considered a "hit" if it had an $\mathrm{IC}_{50}$ value below $2 \mu \mathrm{M}$ (Table 1$)$ and had an IC 50 against the coupled enzymes ( $\mathrm{IC}_{50 \text {, coupled enzyme }}$ ) greater than $10 \mu \mathrm{M}$; these thresholds were chosen so that any hits would have TbGSK3 $\beta$ selectivity greater than 5 -fold. Two new hits against TbGSK3 $\beta$ were discovered, namely, LY2784544 $4^{34}$ and sorafenib ${ }^{35}$ (Table 1 and Figure 4b).

\section{Tf Endocytosis Inhibition and Antitrypanosomal Activity of LY2784544 and Sorafenib}

The hits were tested for inhibition of endocytosis of Tf or BSA. Sorafenib was a slightly better inhibitor of endocytosis (Figure 5a) with $\mathrm{EC}_{50}$ values of $2.7 \mu \mathrm{M}$ for $\mathrm{Tf}$, and $5.9 \mu \mathrm{M}$ for BSA (Table 1), as compared to LY2784544 ( $\mathrm{Tf} \mathrm{EC}_{50}=7.8 \mu \mathrm{M}$ and BSA EC $50=6.2 \mu \mathrm{M}$ ) (Figure 5b). Antitrypanosomal activity of LY2784544 and sorafenib was tested on bloodstream T. brucei. LY2784544 blocked trypanosome proliferation with a $\mathrm{GI}_{50}$ of 1.0 $\mu \mathrm{M}$, and sorafenib had a $\mathrm{GI}_{50}$ of $3.1 \mu \mathrm{M}$ (Table 1). Therefore, both LY2784544 and sorafenib are hits for antitrypanosome lead discovery.

\section{MATERIALS AND METHODS}

\section{Generation of TbGSK3 $\beta$ RNAi Construct and Stable Transfection}

Chromosomal DNA was isolated from CA427 trypanosomes. ${ }^{36}$ An approximately $400 \mathrm{bp}$ fragment of the TbGSK $3 \beta$ gene was amplified using high-fidelity Phusion polymerase (New England Biolabs, Ipswich, MA) and a primer pair designed with assistance from RNAit ${ }^{37}$ that corresponded to the first $400 \mathrm{bp}$ of the TbGSK3 $\beta$ gene: forward primer sequence, ctcgagggatccCGGAACTATTACCGTCGCATGACAAATC; reverse primer sequence, ctcgagaagcttGGAAGTGGCTGCTTGAAGACGTTCTC (lowercase letters are engineered restriction enzyme cut sites, and uppercase letters are specific to the TbGSK3 $\beta$ gene). The 
PCR product was digested with $\mathrm{BamHI}$ and $\mathrm{XhoI}$ and cloned into the $\mathrm{p} 2 \mathrm{~T} 7^{\mathrm{TABlue}}$ trypanosome RNAi vector. ${ }^{23}$

The TbGSK3 $\beta$ :p2T7 ${ }^{\text {TABlue }}$ construct was transfected into bloodstream-form (BSF) trypanosomes by electroporation with slight modifications from a previously published protocol. ${ }^{38}$ Briefly, single-marker BSF trypanosomes ${ }^{23,39}\left(10^{8}\right.$ cells) were transfected with $10 \mu \mathrm{g}$ of plasmid linearized with NotI-HF (NEB, Ipswich, MA) in $200 \mu \mathrm{L}$ of cytomix (120 $\mathrm{mM} \mathrm{KCl}, 0.15 \mathrm{mM} \mathrm{CaCl}_{2}, 10 \mathrm{mM} \mathrm{KPi}$ (pH 7.6), $25 \mathrm{mM}$ HEPES (pH 7.6), 2 mM K${ }_{2}$ EDTA (pH 8.0), $5 \mathrm{mM} \mathrm{MgCl} 2,1 \mathrm{mM}$ hypoxanthine, $0.5 \%$ glucose, $5 \mathrm{mM}$ ATP, $5 \mathrm{mM}$ glutathione). ${ }^{38}$ The electroporation was performed in a $4 \mathrm{~mm}$ cuvette with one pulse at 1.35 $\mathrm{kV}, 50 \mu \mathrm{F}$ capacitance, and $360 \Omega$ resistance. The electroporated cells $(100 \mu \mathrm{L})$ were diluted in $10 \mathrm{~mL}$ of fresh HMI-9 medium and cultured for $15 \mathrm{~h}$. Transfectants were then serially diluted $\left(1: 10^{2}, 1: 10^{3}, 1: 10^{4}\right)$ in HMI-9 containing G418 $(6.5 \mu \mathrm{g} / \mathrm{mL})$ and hygromycin $(5$ $\mu \mathrm{g} / \mathrm{mL}$ ) and plated ( $1 \mathrm{~mL}$ per well of a 24 -well plate). After 5 days of culture, stably transfected clones were selected from plates with fewer than six transfectant-positive wells. The TbGSK3 $\beta$ RNAi cell line was always cultured in HMI-9 containing G418 $(6.5 \mu \mathrm{g} / \mathrm{mL})$ and hygromycin $(5 \mu \mathrm{g} / \mathrm{mL})$ to maintain selection. To induce RNAi, $1 \mu \mathrm{g} / \mathrm{mL}$ tetracyclin (1 $\mu \mathrm{g} / \mathrm{mL})$ was added to the trypanosomes $\left(5 \times 10^{3}\right.$ cells $\left./ \mathrm{mL}\right)$.

\section{Generation of the TbGSK3 $\beta$ Overexpression Construct}

A full-length TbGSK3 $\beta$ gene was amplified from $T$. brucei CA427 genomic DNA by PCR (forward primer, aagcttATGTCGCTCAACCTTACCGATGC; reverse primer, ggatccTTACTTCTTCAGCAGATACTCCCGC). The bluntend PCR product was cloned into pMiniT cloning vector (New England Biolabs). An internal HindIII site was mutated out of the TbGSK $3 \beta$ gene by QuikChange II site-directed PCR mutagenesis (forward primer, GGAGCCAACAACGAAaCTTCCCAGTGGTAATC; reverse primer, GATTACCACTGGGAAGtTTCGTTGTTGGCTCC) following the recommended protocol (Agilent Technologies). The full-length, silent mutant TbGSK $3 \beta$ gene was subsequently cloned into pDex $777^{31}$ using HindII and BamHI.

Transfection into BSF trypanosomes was similar to published methods. ${ }^{40}$ Briefly, singlemarker trypanosomes $\left(4 \times 10^{7}\right)$ were washed with phosphate-buffered saline supplemented with $1 \%$ glucose (PBS-G) and resuspended in $100 \mu \mathrm{L}$ of Amaxa human T-cell nucleofection solution (Lonza Group, Basel, Switzerland) containing NotI-linearized pDex777:TbGSK3 $\beta$ $(10 \mu \mathrm{g})$ plasmid. Trypanosomes were nucleofected with one pulse using protocol X-001 on a Nucleofector $2 \mathrm{~b}$ device (Lonza Group). After nucleofection, trypanosomes were cloned out following described methods (above) with G418 $(6.5 \mu \mathrm{g} / \mathrm{mL})$ and phleomycin $(1.75 \mu \mathrm{g} / \mathrm{mL})$ selection. Stable transfectants were routinely cultured with G418 and phleomycin ( 2.5 $\mu \mathrm{g} / \mathrm{mL}$ ) selection. TbGSK $3 \beta$ overexpression was induced by the addition of tetracycline ( 1 $\mu \mathrm{g} / \mathrm{mL})$ to trypanosomes $\left(5 \times 10^{5} / \mathrm{mL}\right)$.

\section{Western Blot}

TbGSK3 $\beta$ RNAi transfected single-marker BSF T. brucei $\left(2 \times 10^{6}\right)$ induced or uninduced for $48 \mathrm{~h}$ or TbGSK3 $\beta$ :pDex 777 transfected single-marker trypanosomes $\left(1 \times 10^{6}\right)$ induced or uninduced for $3 \mathrm{~h}$ were pelleted and washed once in PBS-G. Trypanosomes were lysed in 
$15 \mu \mathrm{L}$ of SDS sample buffer and heated to $95{ }^{\circ} \mathrm{C}$ for $5 \mathrm{~min}$, and the proteins were separated by SDS-PAGE ( $15 \%$ acrylamide gel) containing stain-free reagent (Bio-Rad, Hercules, CA). The gel was activated (5 min, following the recommended protocol) and imaged using a ChemiDoc MP system (Bio-Rad, Hercules, CA) to determine the amount of protein in each lane. The proteins were then transferred from the gel to the PVDF membrane using a semidry rapid transfer buffer and apparatus (Bio-Rad, Hercules, CA). The membrane was blocked with PBS, $3 \%$ bovine serum albumin, and $0.1 \%$ Tween-20 (blocking buffer) for $1 \mathrm{~h}$. After blocking, primary antibody, which was rabbit polyclonal anti-TbGSK3 $\beta$ antibody (raised against the TbGSK3 $\beta$-specific peptide EVNPQRKRSREAPPC (Genscript, Piscataway, NJ)), was diluted (1:2000) in blocking buffer and incubated with the membrane for $1 \mathrm{~h}$. Excess primary antibody was washed three times (5 min each) in PBS and $0.1 \%$ Tween-20 (PBS-T), and then secondary antibody, which was alkaline phosphataseconjugated goat antirabbit (Bio-Rad, Hercules, CA), was diluted (1:2000) in blocking buffer and incubated with the membrane for $1 \mathrm{~h}$. Unbound secondary antibody was washed off twice with PBS-T, and the membrane was developed with Immune-Star AP substrate (BioRad, Hercules, CA) for 3 min. The developed membrane was imaged on a Bio-Rad ChemiDoc MP system.

\section{Endocytosis Assay}

Bloodstream CA427 T. brucei $\left(5 \times 10^{5}\right), 48 \mathrm{~h}$ of induced or uninduced TbGSK3 $\beta$ RNAi transfected single-marker cells or $3 \mathrm{~h}$ of induced or uninduced TbGSK $3 \beta$ overexpression cells cultured in HMI-9 medium were resuspended in $1 \mathrm{~mL}$ of serum-free HMI-9. For inhibitor treatment, each compound (at various concentrations) was delivered in $1 \mu \mathrm{L}$ of DMSO. The cells were incubated for 3-5 min in the presence of inhibitor and then BSAAlexaFluor647 conjugate (BSA-A647, $50 \mu \mathrm{g} / \mathrm{mL}$, Invitrogen, Eugene, OR) and either transferrin-AlexaFluor488 conjugate (Tf-A488, $25 \mu \mathrm{g} / \mathrm{mL}$, Invitrogen, Eugene, OR) or Haptaglobin phenotype 1-1 conjugated to AlexaFluor488 (following AlexaFluor protein labeling kit (Life Technologies, Invitrogen, Eugene, OR)) in complex with hemoglobin (38 $\mathrm{nM}$ ) were added. Trypanosomes were incubated for $15 \mathrm{~min}$ at $37^{\circ} \mathrm{C}, 5 \% \mathrm{CO}_{2}$. A control aliquot of serum-free HMI-9 medium and Tf-A488 and BSA-A647 without cells was also prepared (no cell control). All samples were transferred to ice. The cells were pelleted (2000g, $5 \mathrm{~min}, 4{ }^{\circ} \mathrm{C}$ ), and resuspended in $1 \mathrm{~mL}$ of cold PBS containing $10 \mathrm{mM}$ glucose and propidium iodide (PI) ( $3 \mu \mathrm{M})$. Incubation with PI proceeded for $15 \mathrm{~min}$ (on ice), after which the samples were analyzed by flow cytometry (CyAn ADP analyzer (Beckman Coulter), TfAlexaFluor488 or Hp-Hb-AlexaFluor488: excitation, 488 laser; emission, 530/40 filter. BSA-A647: excitation, 635 laser; emission, 665/20 filter. PI: excitation, 488 laser; emission, 613/20 filter. Using FlowJo version 9 software (Tree Star, Ashland, OR), median fluorescence of each fluorophore was determined for events with similar forward versus sidescatter profiles that were distinguished from the "no cell" control background and were not permeable to propidium iodide.

\section{Expression and Purification of Recombinant TbGSK3 $\beta$}

Full-length TbGSK $3 \beta$ was cloned into the pET21d expression vector in-frame with a Cterminal $6 \times$ His tag. BL21 (DE3) E. coli were transformed with the construct and cultured in terrific broth (TB) supplemented with $1 \%$ glucose to an OD (at $590 \mathrm{~nm}$ ) of 1.8. Expression 
of TbGSK $3 \beta$ was induced with IPTG $(0.5 \mathrm{mM})$ for $3 \mathrm{~h}$ at $32{ }^{\circ} \mathrm{C}$. Cells were harvested and resuspended in lysis buffer (30 mM HEPES (pH 8.0), $300 \mathrm{mM} \mathrm{NaCl}, 10 \%$ glycerol, $10 \mathrm{mM}$ imidazole, $0.2 \mu \mathrm{M}$ PMSF, and $2 \mathrm{mM} \beta$-mercaptoethanol). The bacteria were lysed by sonication and freeze/thaw cycles. Insoluble protein were removed by centrifugation (12 $000 \mathrm{~g}, 45 \mathrm{~min}, 4^{\circ} \mathrm{C}$ ), and the soluble fraction was loaded onto an immobilized metal afinity chromatography (IMAC) column. The column was washed with $30 \mathrm{mM}$ HEPES (pH 8.0), $0.5 \mathrm{M} \mathrm{NaCl}, 10 \%$ glycerol, $20 \mathrm{mM}$ imidazole, $0.02 \%$ Triton $\mathrm{X}-100,2 \mathrm{mM} \beta$ mercaptoethanol. Recombinant TbGSK $3 \beta$ (rTbGSK3 $\beta$ ) was eluted from the IMAC column with $6 \mathrm{~mL}$ of $30 \mathrm{mM}$ HEPES (pH 7.5), $300 \mathrm{mM} \mathrm{NaCl}, 10 \%$ glycerol, $200 \mathrm{mM}$ imidazole, 2 $\mathrm{mM} \beta$-mercaptoethanol. Eluted rTbGSK $3 \beta$ was further fractionated by size-exclusion chromatography (SEC) using a Superdex-200, 10/300 GL column pre-equilibrated with SEC running buffer, $50 \mathrm{mM}$ Tris- $\mathrm{HCl}(\mathrm{pH} 7.5), 100 \mathrm{mM} \mathrm{NaCl}$. Fractions were collected, and a portion of each was analyzed by SDS-PAGE to determine which fraction contained rTbGSK $3 \beta$ (Figure S3). A band corresponding to the molecular weight of $\operatorname{rTbGSK} 3 \beta$ eluted in fractions $13-15$ and was considered the purified enzyme. Purified rTbGSK3 $\beta$ was stored at $-80{ }^{\circ} \mathrm{C}$ in $50 \mathrm{mM}$ Tris- $\mathrm{HCl}(\mathrm{pH} 7.5), 100 \mathrm{mM} \mathrm{NaCl}, 20 \%$ glycerol until used.

\section{In Vitro Kinase Assay}

The enzyme activity of TbGSK $3 \beta$ was measured with an ADP Quest assay (DiscoverRx, Fremont, CA) using a synthetic peptide substrate, GSM (RRRPASVPPSPSLSRHS(pS)HQRR, where (pS) corresponds to phosphorylated serine). Briefly, inhibitors were serially diluted and incubated with $1.25 \mathrm{nM}$ TbGSK $3 \beta$ for $10 \mathrm{~min}$ at room temperature in assay buffer (15 mM HEPES, $\mathrm{pH}$ 7.4, $20 \mathrm{mM} \mathrm{NaCl}, 1 \mathrm{mM}$ EGTA, $0.02 \%$ Tween 20 , and $10 \mathrm{mM} \mathrm{MgCl}_{2}$ ). To initiate the kinase reaction, substrate peptide and ATP were added to a final concentration of $10 \mu \mathrm{M}$ each in a final reaction volume of $20 \mu \mathrm{L}$. The reaction was further incubated for $15 \mathrm{~min}$ at room temperature. The ADP (product) concentration was determined by the addition of $10 \mu \mathrm{L}$ of ADP Quest assay reagent A and $20 \mu \mathrm{L}$ of ADP Quest assay reagent B and incubated at room temperature for $15 \mathrm{~min}$. The fluorescence signal at $590 \mathrm{~nm}$ was measured with a Varioskan fluorescence plate reader. The corresponding $\mathrm{IC}_{50}$ value of the compound was calculated using GraphPad Prism 6 (GraphPad Software, Inc., CA) according to the equation

$$
\% \text { inhibiton }=\min +\frac{\min -\max }{1+10^{\left(\log \mathrm{IC}_{50}-x\right) n}}
$$

where min and max are the $y$ intercepts of the lower and higher baselines, respectively (with assumed slopes of 0), $x$ is the inhibitor concentration, and $n$ is the Hill coefficient.

\section{Proliferation Inhibition Assay}

Bloodstream form (BSF) CA427 trypanosomes $\left(2 \times 10^{3}\right.$ cells $\left./ \mathrm{mL}\right)$ were cultured in $1 \mathrm{~mL}$ of HMI-9 medium. Each TbGSK3 $\beta$ inhibitor was added (at various concentrations) to $1 \mu \mathrm{L}$ of DMSO, and trypanosomes were cultured for $48 \mathrm{~h}$, after which they were counted with a Coulter Counter (Beckman) using a $100 \mu \mathrm{m}$ aperture tube monitoring for particle sizes of between 2.5 and $5 \mu \mathrm{m}$. The growth percentage (compared to the DMSO control) was determined according to the equation 


$$
\% \text { growth }=\frac{[\text { final }]_{\text {treated }}-[\text { initial }]}{[\text { final }]_{\text {control }}-[\text { initial }]} \times 100
$$

where [initial] is the starting cell density, [final $]_{\text {control }}$ is the final cell density in untreated trypanosomes after $48 \mathrm{~h}$, and [final] treated is the final cell density of trypanosomes treated with the inhibitor. The calculated \% growth was plotted versus the TbGSK $3 \beta$ inhibitor concentration, and the dose-response curve was fitted to determine the concentration of inhibitor that inhibited trypanosome growth by $50 \%\left(\mathrm{GI}_{50}\right)$.

\section{DISCUSSION}

\section{Genetic and Small-Molecule Evidence that TbGSK3 $\beta$ Regulates Tf Endocytosis in a Trypanosome}

We used three approaches to document the role of TbGSK3 $\beta$ in Tf endocytosis by $T$. brucei. Genetic manipulation of TbGSK $3 \beta$ protein levels modulated the amount of transferrin taken up: knockdown (Figure 1) decreased Tf endocytosis while overexpression (Figure 3) increased $\mathrm{Tf}$ uptake. Chemical inhibition of the enzyme also decreased $\mathrm{Tf}$ endocytosis (Figure 2). The two TbGSK3 $\beta$ inhibitors, TWS119 and GW8510, represent different chemotypes (pyrrolopyrimidine and thiazoloindole, respectively), which reduces the likelihood of inadvertently blocking some other activity that is not linked to TbGSK3 $\beta$. Furthermore, Tf endocytosis was not blocked by PKI-166, a pyrrolopyrimidine that did not inhibit TbGSK3 $\beta$ (Figure S1). Combined, these data provide compelling evidence that TbGSK $3 \beta$ is important for Tf endocytosis.

Interestingly, the endocytosis of BSA or Hp-Hb was not affected when TbGSK3 $\beta$ was knocked down (Figure 1d) or after TWS119 treatment of trypanosomes (Figure 2d). These data illustrate for the first time that the endocytic pathway of two GPI-anchored receptors (TfR and $\mathrm{HpHbR}$ ) might be differentially regulated. Furthermore, the uptake of $\mathrm{BSA}^{25}$ is functionally distinguishable from the receptor-mediated route of Tf. Similarly, in HeLa cells, the phagocytosis of viral particles may be subjected to differential regulation: GSK3 $\beta$ knockdown decreases clathrin-dependent infection by the vesicular stomatitis virus but increases caveolin/lipid raft-mediated infection by simian virus $40 .{ }^{41}$

In human cells, there is no report that GSK $3 \beta$ regulates Tf endocytosis. With this in mind, we tested the ability of GW8510 and TWS119, which inhibit human GSK3 $\beta,{ }^{28}$ to inhibit Tf endocytosis in HeLa cells. Neither TbGSK $3 \beta$ inhibitor affected Tf endocytosis in HeLa cells (Figure 6). As a control to validate our experimental method, we used semiselective protein kinase inhibitor H-89, which inhibits Tf endocytosis in HeLa cells. ${ }^{42}$ In contrast to TWS119 and GW8510, H-89 decreased Tf endocytosis in HeLa cells (Figure 6). These data indicate that TbGSK $3 \beta$, although $70 \%$ identical in protein sequence to human GSK3 $\beta$, has unique functions in trypanosomes as compared to its homologue in human cells. 


\section{TWS119 Is a Chemical Tool for Studying Tf Endocytosis in a Trypanosome}

Chemical biology can provide new reagents to complement or extend genetic studies of biological processes. ${ }^{13,43}$ In this work, we identified two new compounds that inhibit recombinant TbGSK3 $\beta$ in vitro at low concentrations. Even though a compound inhibits TbGSK $3 \beta$ in vitro, it could be active against other enzymes in vivo. In this case, screening the activity of each TbGSK $3 \beta$ inhibitor against the Tf endocytosis phenotype provides a different metric for target selectivity in trypanosomes. TWS119 has comparable $\mathrm{IC}_{50}$ and $\mathrm{GI}_{50}$ values (in the range of $1 \mu \mathrm{M}$, Table 1). The treatment of trypanosomes with TWS119 (2 $\mu \mathrm{M}$ ) decreased the $\mathrm{Tf}$ endocytosis (Table 1), but the probe had no effect on BSA or Hp-Hb endocytosis, phenocopying the genetic knockdown of TbGSK3 $\beta$ (Figure 1). Also, the TWS119 treatment countered the increase in Tf endocytosis after the overexpression of TbGSK3 $\beta$ (Figure $3 \mathrm{c}$ ). Therefore, we propose TWS119 as a chemical probe for studying signaling pathways and effector proteins regulated by TbGSK $3 \beta$ in the trypanosome. (PKI-166 will be an important control molecule for these studies because it is a close structural analog of TWS119, but it does not inhibit TbGSK3 $\beta$ in biochemical assays or Tf endocytosis in trypanosomes (Figure S1)).

There are several advantages to using a chemical probe to study trypanosome biology to complement the genetic knockdown of TbGSK3 $\beta$. First, the chemical tool shifts the kinetics of experiments to minutes or hours after exposure to the probe, instead of days after a genetic knockdown, to observe the desired phenotype. Second, enzyme inhibition by a chemical tool allows any physiology that is enzyme-activity-dependent to be studied. Finally, the titration of the chemical probe dose and exposure time allows an investigator to tease out subtle effects on the targets of the chemical probe.

A potential disadvantage of using a chemical probe for biological experiments is the penchant for so-called off-target effects, ${ }^{44,45}$ a problem that has also been noted for RNAi as well as CRISPR/Cas9 technologies. ${ }^{46-48}$ The solution to this problem of spurious inactivation of other kinases by TWS119 lies in ensuring that the genetic knockdown of the target gene produces the same phenotype as using the chemical probe to inactivate the enzyme. In our study of Tf endocytosis regulation by TbGSK3 $\beta$, only TWS119, out of several inhibitors of the enzyme tested, phenocopied the genetic knockdown and so qualifies as a chemical surrogate for the genetic loss of TbGSK $3 \beta$ function in vivo. However, it is important to note that TWS119 (as well as TbGSK3 $\beta$ ) may impact other biological processes that were not assayed in this article. A clear extension of this work will be determining whether TbGSK $3 \beta$ regulates other biological processes, especially because human GSK $3 \beta$ regulates multiple pathways (reviewed in refs 49-51). Then it will be interesting to ascertain if TWS119 also affects those pathways.

\section{New Scaffolds for Anti-Trypanosome Hit-to-Lead Drug Discovery}

TbGSK $3 \beta$ has been the subject of several target-based hit discovery projects $22,32,52$ that focused on libraries of human GSK3 $\beta$ inhibitors or inhibitors of closely related protein kinases, for example, CDK. ${ }^{22}$ We took an alternative strategy of screening a library of 70 orally bioavailable tyrosine kinase inhibitors (Table S1) on the basis of our surprising observation that the human EGFR inhibitor, lapatinib (a 4-anilinoquinazoline), associated 
with TbGSK $3 \beta .{ }^{16}$ By doing this, two new TbGSK $3 \beta$ inhibitors were discovered: sorafenib and LY2784544. These drugs inhibited trypanosome proliferation at concentrations below 3 $\mu \mathrm{M}$. Because the compounds are orally bioavailable, they are excellent candidates for antitrypanosome lead discovery efforts, which would focus on modifying the scaffold to improve antiparasite activity and selectivity over host cell activity as has been demonstrated for lapatinib. ${ }^{53}$

In conclusion, we have identified the first protein kinase involved in trypanosome $\mathrm{Tf}$ endocytosis, TbGSK3 $\beta$. A genetic knockdown of TbGSK $3 \beta$ or treatment with TWS119 blocked Tf endocytosis but had no effect on BSA or HpHb endocytosis. We propose using TWS119 as a chemical tool to begin parsing mechanistic details of endocytosis in the trypanosome. Furthermore, the screen for novel TbGSK $3 \beta$ inhibitors from a library of protein tyrosine kinase inhibitors identified two new orally bioavailable antitrypanosome hits that are either in clinical trials or are FDA-approved for indications other than trypanosomiasis. A medicinal chemistry initiative to improve the antitrypanosome properties of the scaffolds is warranted and will benefit from structure-guided docking of these scaffolds to structures of TbGSK $3 \beta^{54-57}$

\section{Supplementary Material}

Refer to Web version on PubMed Central for supplementary material.

\section{ACKNOWLEDGMENTS}

Recombinant TbGSK3 $\beta$ was purified by David Chereau (96 Proteins, South San Francisco, CA). This work was supported by NIH grants R01AI103476 (D.C.S. and K.M.-W.) and R56AI099476 (M.P. and K.M.-W.).

\section{REFERENCES}

(1). Schell D, Evers R, Preis D, Ziegelbauer K, Kiefer H, Lottspeich F, Cornelissen AW, Overath P. A transferrin-binding protein of Trypanosoma brucei is encoded by one of the genes in the variant surface glycoprotein gene expression site. EMBO J. 1991; 10:1061-1066. [PubMed: 1845367]

(2). Steverding D, Stierhof YD, Chaudhri M, Ligtenberg M, Schell D, Beck-Sickinger AG, Overath P. ESAG 6 and 7 products of Trypanosoma brucei form a transferrin binding protein complex. Eur. J. Cell Biol. 1994; 64:78-87. [PubMed: 7957316]

(3). Steverding D, Stierhof YD, Fuchs H, Tauber R, Overath P. Transferrin-binding protein complex is the receptor for transferrin uptake in Trypanosoma brucei. J. Cell Biol. 1995; 131:1173-1182. [PubMed: 8522581]

(4). Steverding D. The transferrin receptor of Trypanosoma brucei. Parasitol. Int. 2000; 48:191-198. [PubMed: 11227758]

(5). Borst P, Fairlamb AH. Surface receptors and transporters of Trypanosoma brucei. Annu. Rev. Microbiol. 1998; 52:745-778. [PubMed: 9891812]

(6). Cao H, Chen J, Krueger EW, McNiven MA. SRC-mediated phosphorylation of dynamin and cortactin regulates the "constitutive" endocytosis of transferrin. Mol. Cell. Biol. 2010; 30:781792. [PubMed: 19995918]

(7). Jones NG, Thomas EB, Brown E, AADickens NJ, Hammarton TC, Mottram JC. Regulators of Trypanosoma brucei cell cycle progression and differentiation identified using a kinome-wide RNAi screen. PLoS Pathog. 2014; 10:e1003886. [PubMed: 24453978]

(8). Parsons M, Worthey EA, Ward PN, Mottram JC. Comparative analysis of the kinomes of three pathogenic trypanosomatids: Leishmania major, Trypanosoma brucei and Trypanosoma cruzi. BMC Genomics. 2005; 6:127. [PubMed: 16164760] 
(9). Subramanya S, Hardin CF, Steverding D, Mensa-Wilmot K. Glycosylphosphatidylinositol-specific phospholipase $\mathrm{C}$ regulates transferrin endocytosis in the African trypanosome. Biochem. J. 2009; 417:685-694. [PubMed: 18785878]

(10). Subramanya S, Mensa-Wilmot K. Diacylglycerol-stimulated endocytosis of transferrin in trypanosomatids is dependent on tyrosine kinase activity. PLoS One. 2010; 5:e8538. [PubMed: 20049089]

(11). Schenone M, Dancik V, Wagner BK, Clemons PA. Target identification and mechanism of action in chemical biology and drug discovery. Nat. Chem. Biol. 2013; 9:232-240. [PubMed: 23508189]

(12). Rabinovitch M, Topper G, Cristello P, Rich A. Receptor-mediated entry of peroxidases into the parasitophorous vacuoles of macrophages infected with Leishmania mexicana amazonensis. J. Leukocyte Biol. 1985; 37:247-261. [PubMed: 3855437]

(13). Mayer TU. Chemical genetics: tailoring tools for cell biology. Trends Cell Biol. 2003; 13:270277. [PubMed: 12742171]

(14). Wood ER, Truesdale AT, McDonald OB, Yuan D, Hassell A, Dickerson SH, Ellis B, Pennisi C, Horne E, Lackey K, Alligood KJ, Rusnak DW, Gilmer TM, Shewchuk L. A unique structure for epidermal growth factor receptor bound to GW572016 (lapatinib). Cancer Res. 2004; 64:66526659. [PubMed: 15374980]

(15). Xia W, Mullin RJ, Keith BR, Liu LH, Ma H, Rusnak DW, Owens G, Alligood KJ, Spector NL. Anti-tumor activity of GW572016: a dual tyrosine kinase inhibitor blocks EGF activation of EGFR/erbB2 and downstream Erk1/2 and AKT pathways. Oncogene. 2002; 21:6255-6263. [PubMed: 12214266]

(16). Katiyar S, Kufareva I, Behera R, Thomas SM, Ogata Y, Pollastri M, Abagyan R, Mensa-Wilmot K. Lapatinib-binding protein kinases in the african trypanosome: identification of cellular targets for kinase-directed chemical scaffolds. PLoS One. 2013; 8:e56150. [PubMed: 23437089]

(17). Li Z, Gourguechon S, Wang CC. Tousled-like kinase in a microbial eukaryote regulates spindle assembly and S-phase progression by interacting with Aurora kinase and chromatin assembly factors. J. Cell Sci. 2007; 120:3883-3894. [PubMed: 17940067]

(18). Urbaniak MD. Casein kinase 1 isoform 2 is essential for bloodstream form Trypanosoma brucei. Mol. Biochem. Parasitol. 2009; 166:183-185. [PubMed: 19450734]

(19). Alsford S, Turner DJ, Obado SO, Sanchez-Flores A, Glover L, Berriman M, Hertz-Fowler C, Horn D. High-throughput phenotyping using parallel sequencing of RNA interference targets in the African trypanosome. Genome Res. 2011; 21:915-924. [PubMed: 21363968]

(20). Mackey ZB, Koupparis K, Nishino M, McKerrow JH. High-throughput analysis of an RNAi library identifies novel kinase targets in Trypanosoma brucei. Chem. Biol. Drug Des. 2011; 78:454-463. [PubMed: 21668652]

(21). Schell D, Borowy NK, Overath P. Transferrin is a growth factor for the bloodstream form of Trypanosoma brucei. Z. Parasitenkd. 1991; 77:558-560.

(22). Ojo KK, Gillespie JR, Riechers AJ, Napuli AJ, Verlinde CL, Buckner FS, Gelb MH, Domostoj MM, Wells SJ, Scheer A, Wells TN, Van Voorhis WC. Glycogen synthase kinase 3 is a potential drug target for African trypanosomiasis therapy. Antimicrob. Agents Chemother. 2008; 52:3710 3717. [PubMed: 18644955]

(23). Alibu VP, Storm L, Haile S, Clayton C, Horn D. A doubly inducible system for RNA interference and rapid RNAi plasmid construction in Trypanosoma brucei. Mol. Biochem. Parasitol. 2005; 139:75-82. [PubMed: 15610821]

(24). Higgins MK, Tkachenko O, Brown A, Reed J, Raper J, Carrington M. Structure of the trypanosome haptoglobin-hemoglobin receptor and implications for nutrient uptake and innate immunity. Proc. Natl. Acad. Sci. U. S. A. 2013; 110:1905-1910. [PubMed: 23319650]

(25). Coppens I, Opperdoes FR, Courtoy PJ, Baudhuin P. Receptor-mediated endocytosis in the bloodstream form of Trypanosoma brucei. J. Protozool. 1987; 34:465-473. [PubMed: 2828605]

(26). Gadelha C, Rothery S, Morphew M, McIntosh JR, Severs NJ, Gull K. Membrane domains and flagellar pocket boundaries are influenced by the cytoskeleton in African trypanosomes. Proc. Natl. Acad. Sci. U. S. A. 2009; 106:17425-17430. [PubMed: 19805090] 
(27). Johnson K, Liu L, Majdzadeh N, Chavez C, Chin PC, Morrison B, Wang L, Park J, Chugh P, Chen HM, D'Mello SR. Inhibition of neuronal apoptosis by the cyclin-dependent kinase inhibitor GW8510: identification of 3' substituted indolones as a scaffold for the development of neuroprotective drugs. J. Neurochem. 2005; 93:538-548. [PubMed: 15836613]

(28). Ding S, Wu TY, Brinker A, Peters EC, Hur W, Gray NS, Schultz PG. Synthetic small molecules that control stem cell fate. Proc. Natl. Acad. Sci. U. S. A. 2003; 100:7632-7637. [PubMed: 12794184]

(29). Mellinghoff IK, Tran C, Sawyers CL. Growth inhibitory effects of the dual ErbB1/ErbB2 tyrosine kinase inhibitor PKI-166 on human prostate cancer xenografts. Cancer Res. 2002; 62:5254-5259. [PubMed: 12234993]

(30). Behera R, Thomas SM, Mensa-Wilmot K. New chemical scaffolds for human african trypanosomiasis lead discovery from a screen of tyrosine kinase inhibitor drugs. Antimicrob. Agents Chemother. 2014; 58:2202-2210. [PubMed: 24468788]

(31). Poon SK, Peacock L, Gibson W, Gull K, Kelly S. A modular and optimized single marker system for generating Trypanosoma brucei cell lines expressing T7 RNA polymerase and the tetracycline repressor. Open Biol. 2012; 2:110037. [PubMed: 22645659]

(32). Urich R, Grimaldi R, Luksch T, Frearson JA, Brenk R, Wyatt PG. The design and synthesis of potent and selective inhibitors of Trypanosoma brucei glycogen synthase kinase 3 for the treatment of human African trypanosomiasis. J. Med. Chem. 2014; 57:7536-7549. [PubMed: 25198388]

(33). Swinney ZT, Haubrich BA, Xia S, Ramesha C, Gomez SR, Guyett P, Mensa-Wilmot K, Swinney DC. A four-point screening method for assessing molecular mechanism of action (MMOA) identifies tideglusib as a time-dependent inhibitor of Trypanosoma brucei GSK3beta. PLoS Neglected Trop. Dis. 2016; 10:e004506.

(34). Ma L, Clayton JR, Walgren RA, Zhao B, Evans RJ, Smith MC, Heinz-Taheny KM, Kreklau EL, Bloem L, Pitou C, Shen W, Strelow JM, Halstead C, Rempala ME, Parthasarathy S, Gillig JR, Heinz LJ, Pei H, Wang Y, Stancato LF, Dowless MS, Iversen PW, Burkholder TP. Discovery and characterization of LY2784544, a small-molecule tyrosine kinase inhibitor of JAK2V617F. Blood Cancer Journal. 2013; 3:e109. [PubMed: 23584399]

(35). Wilhelm SM, Carter C, Tang L, Wilkie D, McNabola A, Rong H, Chen C, Zhang X, Vincent P, McHugh M, Cao Y, Shujath J, Gawlak S, Eveleigh D, Rowley B, Liu L, Adnane L, Lynch M, Auclair D, Taylor I, Gedrich R, Voznesensky A, Riedl B, Post LE, Bollag G, Trail PA. BAY 439006 exhibits broad spectrum oral antitumor activity and targets the RAF/ MEK/ERK pathway and receptor tyrosine kinases involved in tumor progression and angiogenesis. Cancer Res. 2004; 64:7099-7109. [PubMed: 15466206]

(36). Medina-Acosta E, Cross GA. Rapid isolation of DNA from trypanosomatid protozoa using a simple 'mini-prep' procedure. Mol. Biochem. Parasitol. 1993; 59:327-329. [PubMed: 8341329]

(37). Redmond S, Vadivelu J, Field MC. RNAit: an automated web-based tool for the selection of RNAi targets in Trypanosoma brucei. Mol. Biochem. Parasitol. 2003; 128:115-118. [PubMed: 12706807]

(38). Subramanya S, Mensa-Wilmot K. Regulated cleavage of intracellular glycosylphosphatidylinositol in a trypanosome. Peroxisome-to-endoplasmic reticulum translocation of a phospholipase C. FEBS J. 2006; 273:2110-2126. [PubMed: 16649989]

(39). Wirtz E, Leal S, Ochatt C, Cross GA. A tightly regulated inducible expression system for conditional gene knock-outs and dominant-negative genetics in Trypanosoma brucei. Mol. Biochem. Parasitol. 1999; 99:89-101. [PubMed: 10215027]

(40). Burkard G, Fragoso CM, Roditi I. Highly efficient stable transformation of bloodstream forms of Trypanosoma brucei. Mol. Biochem. Parasitol. 2007; 153:220-223. [PubMed: 17408766]

(41). Pelkmans L, Fava E, Grabner H, Hannus M, Habermann B, Krausz E, Zerial M. Genome-wide analysis of human kinases in clathrin- and caveolae/raft-mediated endocytosis. Nature. 2005; 436:78-86. [PubMed: 15889048]

(42). Cotlin LF, Siddiqui MA, Simpson F, Collawn JF. Casein kinase II activity is required for transferrin receptor endocytosis. J. Biol. Chem. 1999; 274:30550-30556. [PubMed: 10521437] 
(43). Wijdeven RH, Neefjes J, Ovaa H. How chemistry supports cell biology: the chemical toolbox at your service. Trends Cell Biol. 2014; 24:751. [PubMed: 25108565]

(44). Arrowsmith CH, Audia JE, Austin C, Baell J, Bennett J, Blagg J, Bountra C, Brennan PE, Brown PJ, Bunnage ME, Buser-Doepner C, Campbell RM, Carter AJ, Cohen P, Copeland RA, Cravatt B, Dahlin JL, Dhanak D, Edwards AM, Frederiksen M, Frye SV, Gray N, Grimshaw CE, Hepworth D, Howe T, Huber KV, Jin J, Knapp S, Kotz JD, Kruger RG, Lowe D, Mader MM, Marsden B, Mueller-Fahrnow A, Muller S, O'Hagan RC, Overington JP, Owen DR, Rosenberg SH, Roth B, Ross R, Schapira M, Schreiber SL, Shoichet B, Sundstrom M, Superti-Furga G, Taunton J, Toledo-Sherman L, Walpole C, Walters MA, Willson TM, Workman P, Young RN, Zuercher WJ. The promise and peril of chemical probes. Nat. Chem. Biol. 2015; 11:536-541. [PubMed: 26196764]

(45). Woodland A, Grimaldi R, Luksch T, Cleghorn LAT, Ojo KK, Van Voorhis WC, Brenk R, Frearson JA, Gilbert IH, Wyatt PG. From on-target to off-target activity: identification and optimization of Trypanosoma brucei GSK3 inhibitors and their characterisation as antiTrypanosoma brucei drug discovery lead molecules. ChemMedChem. 2013; 8:1127. [PubMed: 23776181]

(46). Jackson AL, Bartz SR, Schelter J, Kobayashi SV, Burchard J, Mao M, Li B, Cavet G, Linsley PS. Expression profiling reveals off-target gene regulation by RNAi. Nat. Biotechnol. 2003; 21:635637. [PubMed: 12754523]

(47). Anderson EM, Haupt A, Schiel JA, Chou E, Machado HB, Strezoska Z, Lenger S, McClelland S, Birmingham A, Vermeulen A, Smith A. Systematic analysis of CRISPR-Cas9 mismatch tolerance reveals low levels of off-target activity. J. Biotechnol. 2015; 211:56-65. [PubMed: 26189696]

(48). Senthil-Kumar M, Mysore KS. Caveat of RNAi in plants: the off-target effect. Methods Mol. Biol. 2011; 744:13-25. [PubMed: 21533683]

(49). Seira O, Del Rio JA. Glycogen synthase kinase 3 beta (GSK3beta) at the tip of neuronal development and regeneration. Mol. Neurobiol. 2014; 49:931-944. [PubMed: 24158777]

(50). Rayasam GV, Tulasi VK, Sodhi R, Davis JA, Ray A. Glycogen synthase kinase 3: more than a namesake. Br. J. Pharmacol. 2009; 156:885-898. [PubMed: 19366350]

(51). Grimes CA, Jope RS. The multifaceted roles of glycogen synthase kinase 3beta in cellular signaling. Prog. Neurobiol. 2001; 65:391-426. [PubMed: 11527574]

(52). Ojo KK, Arakaki TL, Napuli AJ, Inampudi KK, Keyloun KR, Zhang L, Hol WG, Verlinde CL, Merritt EA, Van Voorhis WC. Structure determination of glycogen synthase kinase-3 from Leishmania major and comparative inhibitor structure-activity relationships with Trypanosoma brucei GSK-3. Mol. Biochem. Parasitol. 2011; 176:98-108. [PubMed: 21195115]

(53). Patel G, Karver CE, Behera R, Guyett PJ, Sullenberger C, Edwards P, Roncal NE, Mensa-Wilmot K, Pollastri MP. Kinase scaffold repurposing for neglected disease drug discovery: discovery of an efficacious, lapatinib-derived lead compound for trypanosomiasis. J. Med. Chem. 2013; 56:3820-3832. [PubMed: 23597080]

(54). Vulpetti A, Crivori P, Cameron A, Bertrand J, Brasca MG, D’ Alessio R, Pevarello P. Structurebased approaches to improve selectivity: CDK2-GSK3beta binding site analysis. J. Chem. Inf. Model. 2005; 45:1282-1290. [PubMed: 16180905]

(55). Ojo KK, Arakaki TL, Napuli AJ, Inampudi KK, Keyloun KR, Zhang L, Hol WG, Verlinde CL, Merritt EA, Van Voorhis WC. Structure determination of glycogen synthase kinase-3 from Leishmania major and comparative inhibitor structure-activity relationships with Trypanosoma brucei GSK-3. Mol. Biochem. Parasitol. 2011; 176:98-108. [PubMed: 21195115]

(56). Osolodkin DI, Palyulin VA, Zefirov NS. Structure-based virtual screening of glycogen synthase kinase 3beta inhibitors: analysis of scoring functions applied to large true actives and decoy sets. Chem. Biol. Drug Des. 2011; 78:378-390. [PubMed: 21679374]

(57). Darshit BS, Balaji B, Rani P, Ramanathan M. Identification and in vitro evaluation of new leads as selective and competitive glycogen synthase kinase-3beta inhibitors through ligand and structure based drug design. J. Mol. Graphics Modell. 2014; 53:31-47. 
a
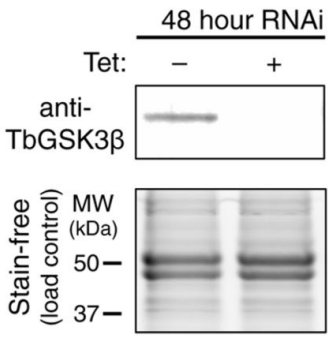

C

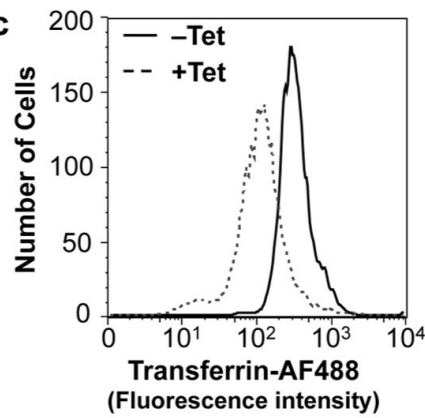

b
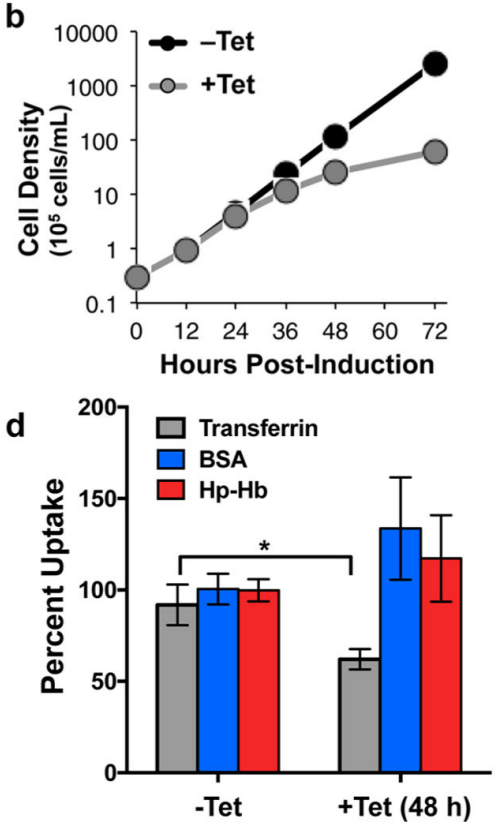

Figure 1.

Knockdown of TbGSK $3 \beta$ reduces Tf endocytosis. Bloodstream form trypanosomes stably transfected with a TbGSK $3 \beta$ RNAi construct were cultured in the absence (-Tet, uninduced) or presence (+Tet, induced) of tetracycline. (a) Western blot of TbGSK3 $\beta$ protein abundance after RNAi induction. After $48 \mathrm{~h}$, trypanosomes $\left(2 \times 10^{6}\right)$ were lysed and the proteins were separated by SDS-PAGE. Protein abundance in the gel was detected with stain-free reagent (Bio-Rad) (load control). Protein was then transferred to a PVDF membrane and developed using anti-TbGSK3 $\beta$ antibody. (b) The proliferation of uninduced (black line) and Tetinduced (gray line) trypanosomes was monitored over $72 \mathrm{~h}$, after inoculation at $5 \times 10^{4} / \mathrm{mL}$ (cells were subcultured to maintain a density of less than $1 \times 10^{6} / \mathrm{mL}$ ). The plotted values were mathematically derived on the basis of dilution factors. The error among three separate experiments is smaller than the data symbols. (c, d) For endocytosis assays, cells were resuspended in serum-free medium containing bovine serum albumin conjugated to Alexafluor649 (BSA-A649) (50 $\mu \mathrm{g} / \mathrm{mL})$ and either transferrin conjugated to Alexafluor488 (Tf-A488, $25 \mu \mathrm{g} / \mathrm{mL}$ ) or haptaglobin conjugated to Alexafluor488 in complex with hemoglobin (HpHb-A488, $38 \mathrm{nM}$ ). Trypanosomes were incubated for $15 \mathrm{~min}$ at $37^{\circ} \mathrm{C}$ and washed, and the amount of fluorophore uptake was measured by flow cytometry. (c) Histogram comparing Tf-A488 uptake by uninduced and induced TbGSK3 $\beta$ RNAi trypanosomes. (d) Average fluorescence uptake (Tf-A488 (gray), BSA-A649 (blue), and Hp$\mathrm{Hb}(\mathrm{red}))$ by uninduced and induced TbGSK $3 \beta$ RNAi trypanosomes in three separate experiments. The median fluorescence in each experiment was normalized to the median fluorescence uptake of the parental trypanosome cell line that does not contain the TbGSK $3 \beta$ RNAi construct. The statistical significance is denoted with an asterisk (*), as determined by a student's $t$ test $(p<0.05)$. 

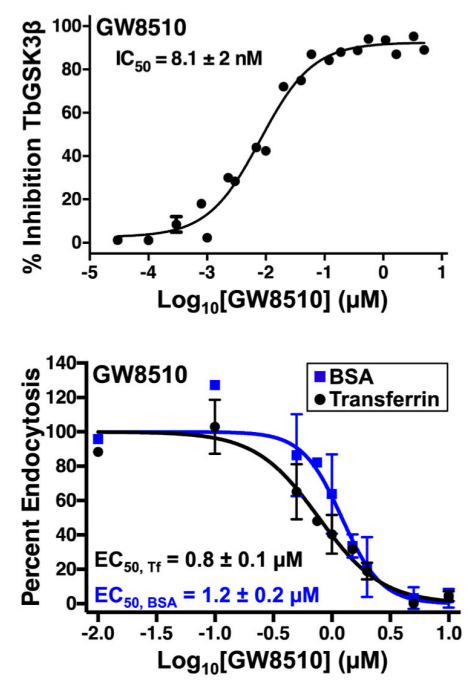

b

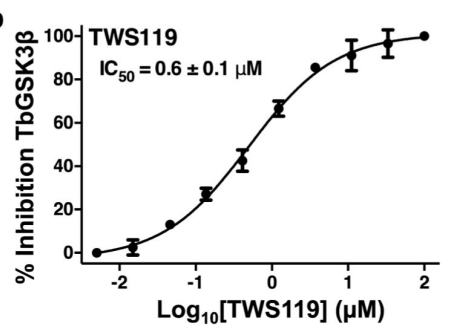

d

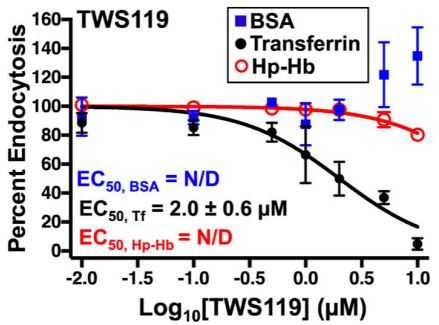

Figure 2.

Dose-response curves of rTbGSK3 $\beta$ activity or endocytosis (Tf or BSA) to GW8510 or TWS119. Activity of rTbGSK $3 \beta$ in various concentrations of (a) the known TbGSK3 $\beta$ inhibitor, GW8510, or (b) the known human GSK3 $\beta$ inhibitor, TWS119. Data from two separate experiments were fit to a dose-response curve using GraphPad Prism 6 software, and the $50 \%$ inhibitory concentration $\left(\mathrm{IC}_{50}\right)$ values were determined. The $95 \%$ confidence interval is reported. The endocytosis of Tf or BSA was determined for trypanosomes $(1 \times$ $10^{6}$ ) treated with varying concentrations of GW8510 (c) or TWS119 (d). Trypanosomes were pretreated with inhibitor for $3 \mathrm{~min}$ on ice, and then Tf-Alexa488 $(25 \mu \mathrm{g} / \mathrm{mL})$, BSAAlexa649 $(50 \mu \mathrm{g} / \mathrm{mL})$, or $\mathrm{Hp}-\mathrm{Hb}(38 \mathrm{nM})$ was added. Trypanosomes were incubated (in the presence of inhibitor) at $37^{\circ} \mathrm{C}$ for $15 \mathrm{~min}$, and the fluorescence uptake was quantified by flow cytometry. Dose-response curves from three separate experiments were fit using GraphPad Prism 6 software. 
a

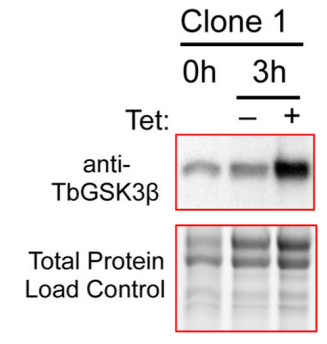

C

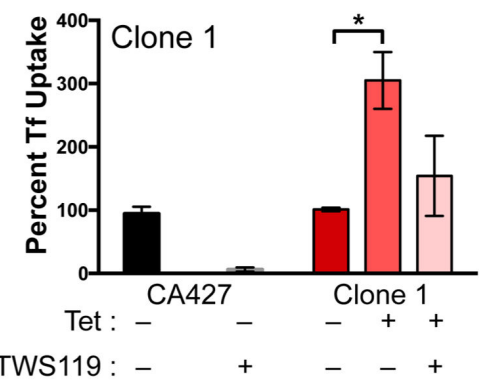

b Induce TbGSK3 $\beta$ overexpression

in trypanosomes

$\checkmark 3 \mathrm{~h}$

Resuspend $\left(5 \times 10^{5} / \mathrm{mL}\right)$ in serum-free media with TWS119

and Transferrin-AlexaFluor488

$\checkmark 15 \mathrm{~min}$

Measure Transferrin uptake

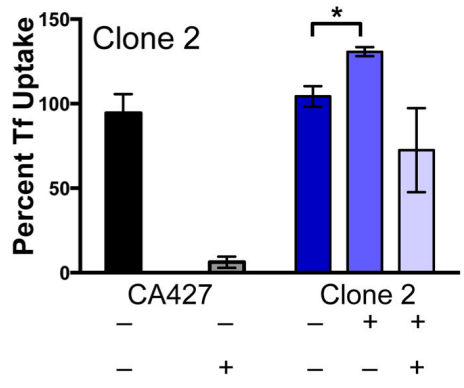

Figure 3.

Overexpression of TbGSK $3 \beta$ increases the uptake of Tf. (a) Western blot of two clones containing inducible overexpression constructs of TbGSK $3 \beta$. Trypanosomes were cultured in the presence (+Tet) or absence (-Tet) of tetracycline for $3 \mathrm{~h}$, or a fraction of cells were taken immediately prior to tetracycline induction $(0 \mathrm{~h})$. For the Western blot, trypanosomes $\left(1 \times 10^{6}\right)$ were harvested, washed with PBS-G, and lysed in $1 \times$ SDS sample buffer. Western blotting was performed as described in Figure 1. (b) Flowchart of the experimental approach used to generate panel (c). TbGSK3 $\beta$ overexpression increases Tf endocytosis, which is countered by the addition of TWS119. Trypanosomes overexpressing TbGSK $3 \beta$ (+Tet) or uninduced cells (-Tet) (after $3 \mathrm{~h}$ ) were treated with TWS119 (10 $\mu \mathrm{M})$ or DMSO solvent control, and the amount of $\mathrm{Tf}$ endocytosed was determined as described in Figure 2. CA427 (control cells) are shown in both panels for reference. Clone 1 (red) and clone 2 (blue). The error from three experiments is represented as error bars; $(*)$ statistical significance $(p<$ 0.05 ) was determined using the student's $t$ test. 
a

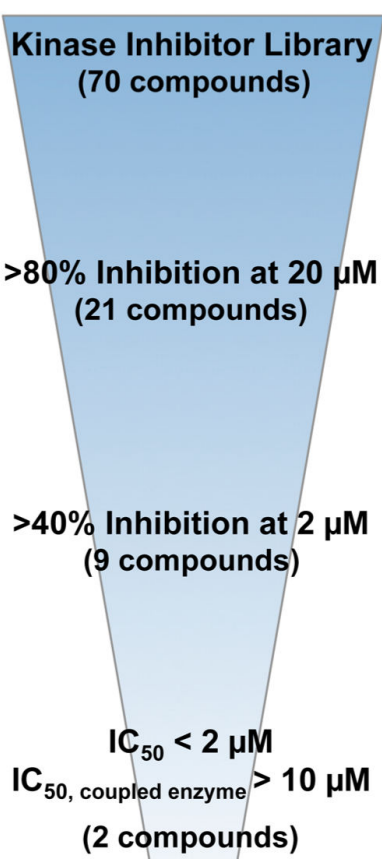

b
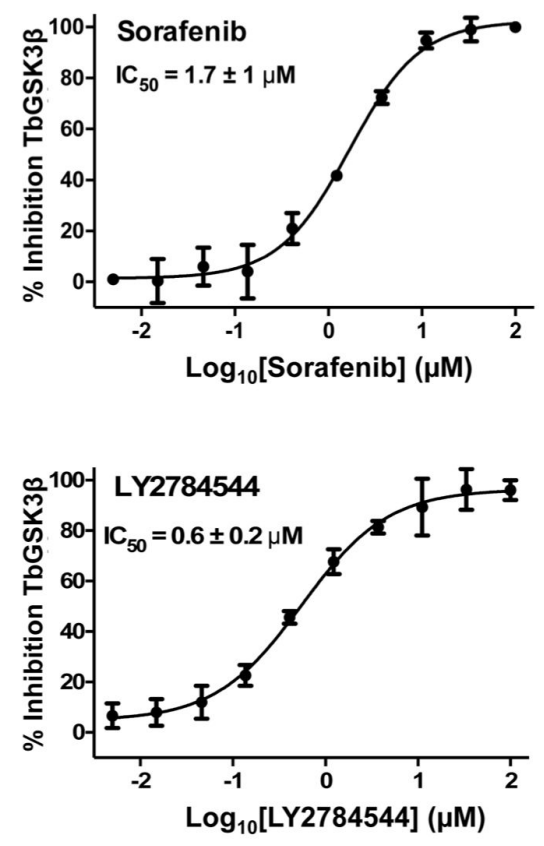

Figure 4.

A focused screen to identify inhibitors of rTbGSK3 $\beta$. (a) A graphical depiction of the screening paradigm. The number of compounds that met each threshold are listed in parentheses. (b) Dose-response curves of the two new rTbGSK3 $\beta$ inhibitors. Data from three separate experiments were fit to a dose-response curve using GraphPad Prism 6 graphing software, and the $50 \%$ inhibitory concentration $\left(\mathrm{IC}_{50}\right)$ values determined. Error at $95 \%$ confidence is reported. 
a

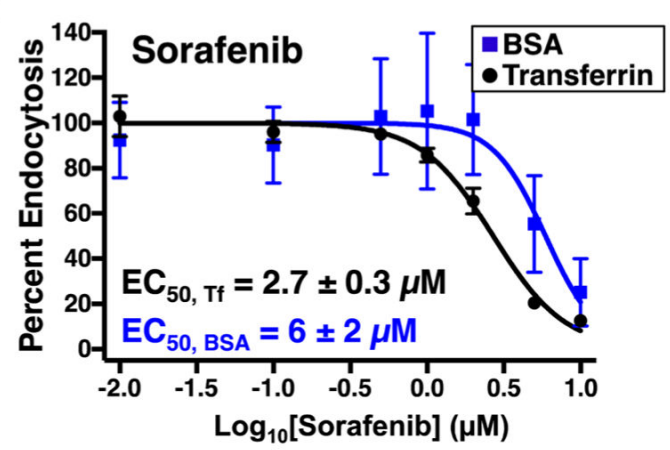

b

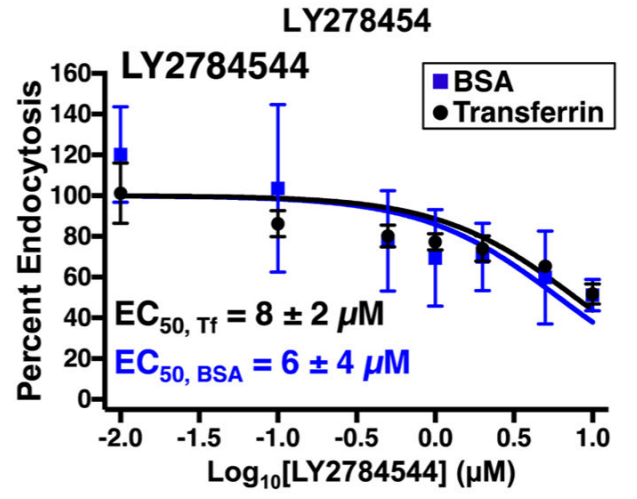

Figure 5.

Dose-response inhibition of endocytosis for Sorafenib and LY2784544. Bloodstream form trypanosomes $\left(1 \times 10^{6}\right)$ were resuspended in serum free medium, and pretreated with varying concentrations of Sorafenib (a) or LY2784544 (b) for 3 min on ice. After pretreatment, Tf-A488 $(25 \mu \mathrm{g} / \mathrm{mL})$ and BSA-649 $(50 \mu \mathrm{g} / \mathrm{mL})$ was added. Trypanosomes were incubated at $37^{\circ} \mathrm{C}$ for $15 \mathrm{~min}$, and fluorescence uptake quantified by flow cytometry. Dose-response curves from three separate experiments were fit using GraphPad Prism 6 graphing software. To fit LY2784544 data, the lower baseline y-intercept was fixed to no endocytosis control values (trypanosomes incubated on ice in the presence of Tf and BSA for duration of experiment). Error is reported at $95 \%$ confidence. 


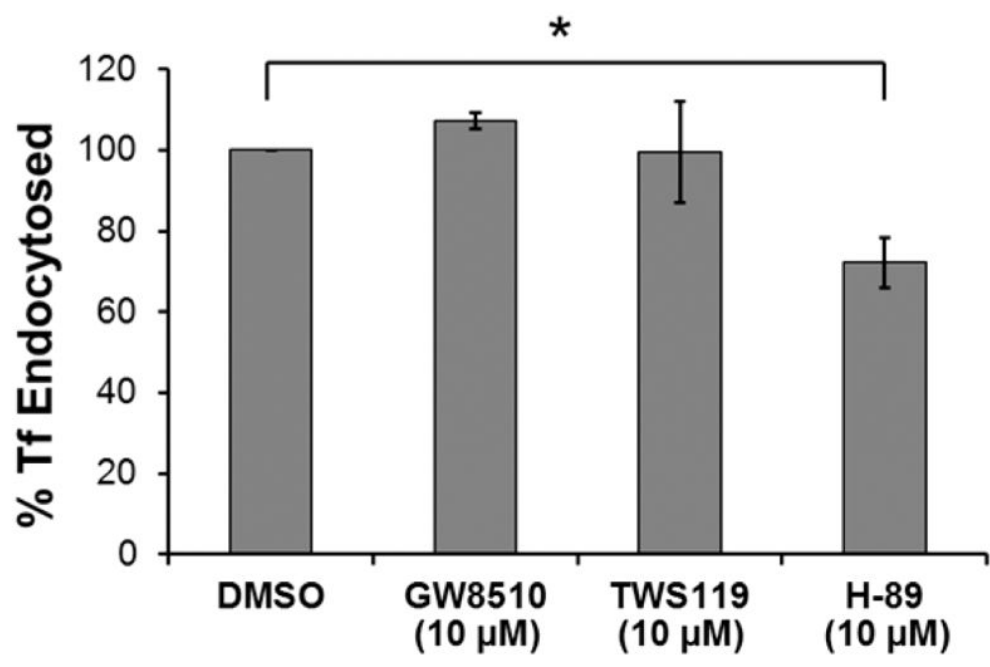

Figure 6.

Chemical inhibition of HeLa cell endocytosis of transferrin. HeLa cells were grown to $75 \%$ confluence in DMEM supplemented with 10\% FBS. The cells were then washed twice with $10 \mathrm{~mL}$ of cold DMEM (serum-free) and incubated for $3 \mathrm{~min}$ in the presence of each compound $(10 \mu \mathrm{M})$ or an equivalent volume of DMSO solvent. The cells were then incubated with Tf-Alexa488 (5 $\mu \mathrm{g} / \mathrm{mL})$ for $15 \mathrm{~min}$ at $37^{\circ} \mathrm{C}$. The HeLa cells were washed twice with ice cold PBS and trypsinized for $3 \mathrm{~min}$ at $37^{\circ} \mathrm{C}$. The unadhered cells were then transferred to microcentrifuge tubes on ice, incubated with propidium iodide $(5 \mu \mathrm{M}, 15 \mathrm{~min}$, on ice), and analyzed by flow cytometry (as described in Materials and Methods). The median fluorescence was normalized to that of the DMSO-treated HeLa cells. Error bars represent one standard deviation in four independent experiments. The statistical significance was determined by the student's $t$ test; an asterisk (*) indicates statistical significance, with $p<0.05$. 


\section{Table 1}

Structures and Activities of TbGSK $3 \beta$ Inhibitors $^{a}$

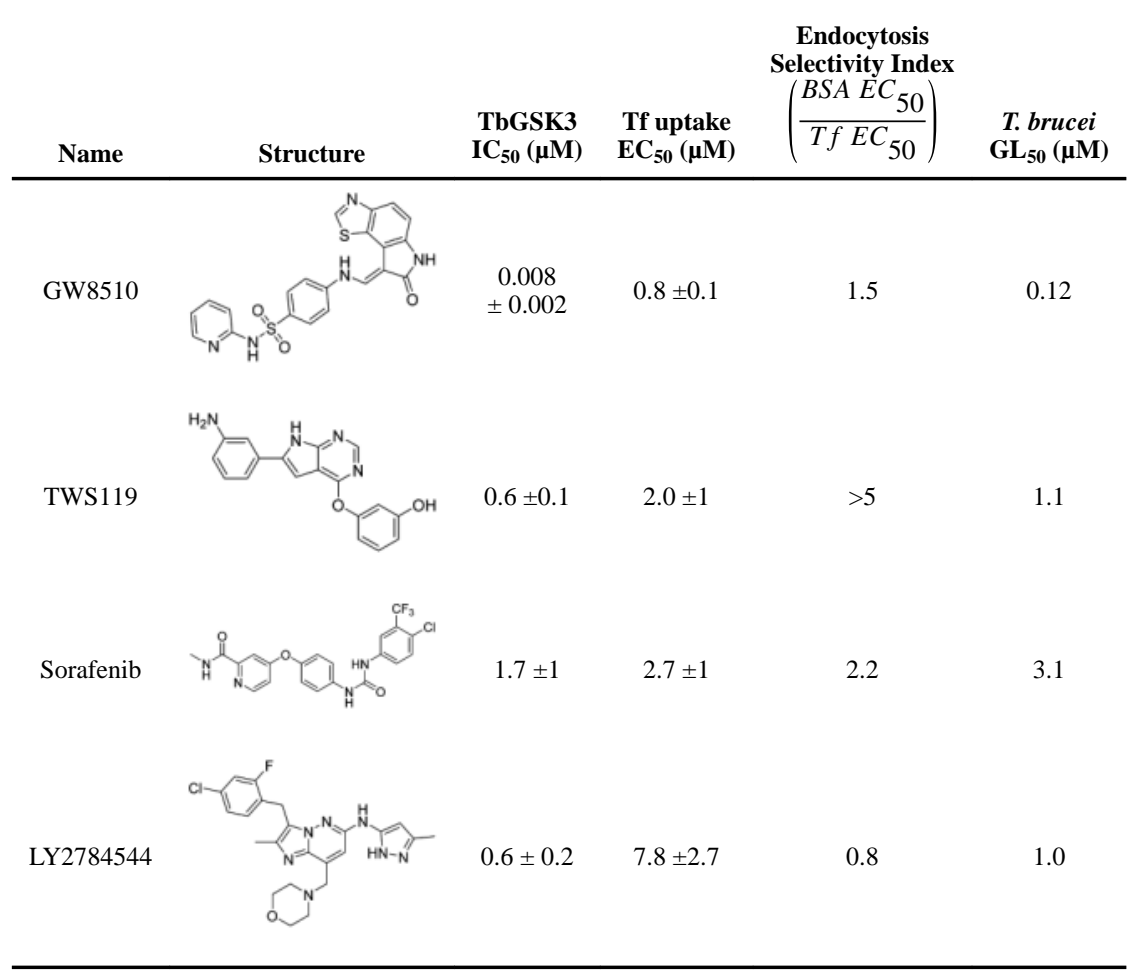

${ }^{a}$ The IC 50 of each compound was determined against rTbGSK3 $\beta$ by in vitro kinase assays as described in Figure 5 and the Materials and Methods section. The $\mathrm{GI}_{50}$ of each compound was determined against axenic cultures of bloodstream trypanosomes as described in Materials and Methods. Tf EC50 is the concentration of each compound that inhibits 50\% of transferrin endocytosis. The endocytosis selectivity was calculated by dividing the BSA EC50 by the Tf EC50; selective inhibition of Tf endocytosis over BSA endocytosis would have a value greater than 1. 